\title{
28. INTERSTITIAL GAS ANALYSIS OF SEDIMENT SAMPLES FROM SITE 368 AND HOLE 369A'
}

Paul R. Doose, Mark W. Sandstrom, Rima Z. Jodele, and I.R. Kaplan, Institute of Geophysics and Planetary Physics, University of California at Los Angeles, Los Angeles, California

\section{INTRODUCTION}

The low molecular weight hydrocarbon gases detected in buried sediments may be useful indicators of the thermal alteration of organic matter in sediments. Hydrocarbon gases can be produced either by bacterial fermentation of, or thermochemical degradation of organic matter. Claypool and Kaplan (1974) have suggested that gases derived from these two sources can be distinguished by chemical composition of the gas and by the $\delta^{13} \mathrm{C}$ value of the methane.

In general, biologically produced gas in marine sediments has a $\delta^{13} \mathrm{C}$ value for methane between $-90 \%$ and $-60 \%$ and has a very low concentration of higher hydrocarbons. Thermal degradation of organic matter will add isotopically heavy methane and higher hydrocarbons to the gas in the sediment. Higher stages of thermal alteration (incipient metamorphism) may degrade even the low molecular weight hydrocarbon gases, resulting in methane with a $\delta^{13} \mathrm{C}$ value between $-50 \%$ and $-30 \%$ (Stahl, 1974). The DSDP gases previously analyzed by Claypool et al. (1973) were primarily of biogenic origin, but increasing amounts of thermochemically produced gas were observed with increase in depth of burial.

In this paper, we report similar mixtures of biogenically produced and thermochemically produced gases in sediments from Site 368 and Hole 369A.

\section{SAMPLING AND ANALYTICAL PROCEDURES}

Sampling and preliminary analysis of the gases were conducted by DSDP shipboard personnel. Samples were taken when gas expansion pockets indicated the presence of gas in the sediment. The gas pockets were sampled by puncturing the core liner and allowing the gas to flow into evacuated glass containers (Gealy and Dubois, 1971). The procedure did not allow quantitative information of gas-to-sediment-volume, thus quantities are reported on a relative volume basis.

\section{GAS CHROMATOGRAPHY}

The composition of hydrocarbons in the gas samples was determined by injecting $50 \mu \ell$ of gas into a HewlettPackard 5830A gas chromatograph, equipped with a flame ionization detector, and 3 meters $\times 0.03$ I.D. stainless steel column packed with n-octane/porasil Durapak substrate. The column was temperatureprogrammed from $-10^{\circ}$ to $100^{\circ} \mathrm{C}$ at $4^{\circ} \mathrm{C} / \mathrm{min}$, allowing baseline separation of all $\mathrm{C}_{1}$ through $\mathrm{C}_{4}$ isomers.

\footnotetext{
'Publication No. 1589.
}

The composition of the individual hydrocarbons was calculated from peak area of each chromatogram and response factors obtained from calibration data.

\section{${ }^{13} \mathrm{C} /{ }^{12} \mathrm{C}$ MEASUREMENTS}

Methane in the gas samples was purified from small amounts of carbon dioxide and ethane in a glass vacuum line by passing it through a trap held at $-186^{\circ} \mathrm{C}$ and collecting it on activated charcoal held at $-186^{\circ} \mathrm{C}$. The methane was quantitatively converted to carbon dioxide for mass spectrometric analysis by combustion in an oxygen atmosphere at $900^{\circ} \mathrm{C}$ according to the procedure described by Kaplan et al. (1970).

The $\delta^{13} \mathrm{C}$ value was measured and reported according to the usual conventions (Kaplan et al., 1970) in the delta notation relative to the PDB standard.

\section{RESULTS}

The hydrocarbon composition of the interstitial gas samples and the $\delta^{13} \mathrm{C}$ values of the methane in the gas, from Site 368 and Hole 369A, are given in Table 1. The error for the hydrocarbon composition is $\pm 0.001 \%$ and the error for the $\delta^{13} \mathrm{C}$ values is $\pm 1 \%$.

The hydrocarbon composition of the gas samples was predominately methane $(>99.10 \%)$, although minor amounts of ethane, propane, and iso-butane were detected. These heavier hydrocarbons increase in concentration with depth in the sediment column.

TABLE 1

Hydrocarbon Composition of Interstitial Gas Samples and $\delta{ }^{13} \mathrm{C}$ Values of Methane in Gas

\begin{tabular}{lcccccc}
\hline & \multirow{2}{*}{$\begin{array}{c}\text { Depth } \\
\text { Section }\end{array}$} & \multicolumn{5}{c}{ Relative \% } \\
\cline { 3 - 5 } & & $\mathrm{CH}_{4}$ & $\mathrm{C}_{2} \mathrm{H}_{6}$ & $\mathrm{C}_{3} \mathrm{H}_{8}$ & $\mathrm{i}^{\mathrm{i}} \mathrm{C}_{4} \mathrm{H}_{10}$ & ${ }^{1}{ }^{13} \mathrm{C}_{\mathrm{PDB}}$ \\
\hline $368-25-1$ & 371 & 99.97 & 0.03 & 0.00 & 0.00 & -64.7 \\
$368-32-4$ & 445 & 99.97 & 0.03 & 0.00 & 0.00 & -61.7 \\
$368-42-3$ & 607 & 99.98 & 0.02 & 0.00 & 0.00 & -57.4 \\
$368-46-4$ & 642 & 99.98 & 0.02 & 0.00 & 0.00 & -57.5 \\
$368-52-5$ & 845 & 99.95 & 0.05 & 0.00 & 0.00 & -54.9 \\
$368-58-5$ & 926 & 99.92 & 0.08 & 0.00 & 0.00 & -56.6 \\
$368-59-3$ & 945 & 99.71 & 0.28 & 0.01 & 0.00 & -56.2 \\
$368-60-4$ & 956 & 99.60 & 0.40 & 0.00 & 0.00 & -57.3 \\
$368-62-4$ & 974 & 99.74 & 0.26 & 0.00 & 0.00 & -51.7 \\
$368-63-2$ & 978 & 99.53 & 0.46 & 0.01 & 0.00 & -53.6 \\
$369 \mathrm{~A}-23-6$ & 260 & 99.91 & 0.06 & 0.03 & 0.00 & -73.7 \\
$369 \mathrm{~A}-27-2$ & 292 & 99.86 & 0.08 & 0.06 & 0.00 & -69.5 \\
$369 \mathrm{~A}-29-2$ & 311 & 99.97 & 0.03 & 0.00 & 0.00 & -73.9 \\
$369 \mathrm{~A}-31-6$ & 335 & 99.96 & 0.04 & 0.00 & 0.00 & -69.5 \\
$369 \mathrm{~A}-33-4$ & 352 & 99.98 & 0.02 & 0.00 & 0.00 & -72.9 \\
$369 \mathrm{~A}-40-4$ & 420 & 99.91 & 0.08 & 0.01 & 0.00 & -67.4 \\
$369 \mathrm{~A}-42-3$ & 436 & 99.73 & 0.23 & 0.04 & 0.00 & -68.8 \\
$369 \mathrm{~A}-43-3$ & 446 & 99.65 & 0.28 & 0.06 & 0.01 & -69.8 \\
$369 \mathrm{~A}-45-2$ & 462 & 99.48 & 0.41 & 0.10 & 0.01 & -67.9 \\
$369 \mathrm{~A}-46-4$ & 475 & 99.46 & 0.42 & 0.11 & 0.01 & -69.7 \\
$369 \mathrm{~A}-46-5$ & 477 & 99.42 & 0.45 & 0.12 & 0.01 & -67.4 \\
$369 \mathrm{~A}-47-5$ & 485 & 99.35 & 0.47 & 0.14 & 0.04 & -65.3 \\
\hline
\end{tabular}


The ${ }^{13} \mathrm{C} /{ }^{12} \mathrm{C}$ ratio of the methane ranges between -64 and $-52 \%$ at Site 368 and between -74 and $-65 \%$ at Hole 369A. The methane at both sites gradually becomes isotopically heavier with depth.

In Figures 1 and 2 the lithologic information that is reported in Leg 41 Shipboard Report is compared with the $\mathrm{C}_{1} / 2 \mathrm{C}_{1}-\mathrm{C}_{4}$ ratio and the $\delta^{13} \mathrm{C}$ of the methane.

\section{DISCUSSION}

The results show the bacterial fermentation of organic matter to be the primary source of methane at both sites.

\section{Site 368}

The sediments sampled at Site 368 , located on the Cape Verde Rise, represent a thick section of terrigenous silty clays and claystones, terminating at 985 meters in black shales interbedded with diabase sills (Shipboard Report, Leg 41). The concentration of ethane is relatively constant throughout the cyclic interbedded silty clays and claystones. In the region of the black shales, higher amounts of organic carbon $(3 \%-11 \%)$, plus the effects of the interbedded diabase sills, are reflected in the increase in concentration of higher hydrocarbons (Figure 1).

Of particular interest is Core 62, Section 4, which is located between diabase sills. Here, the stable carbon isotope ratio of the methane is heavy $\left(-51^{\circ} \% 0\right)$ which is

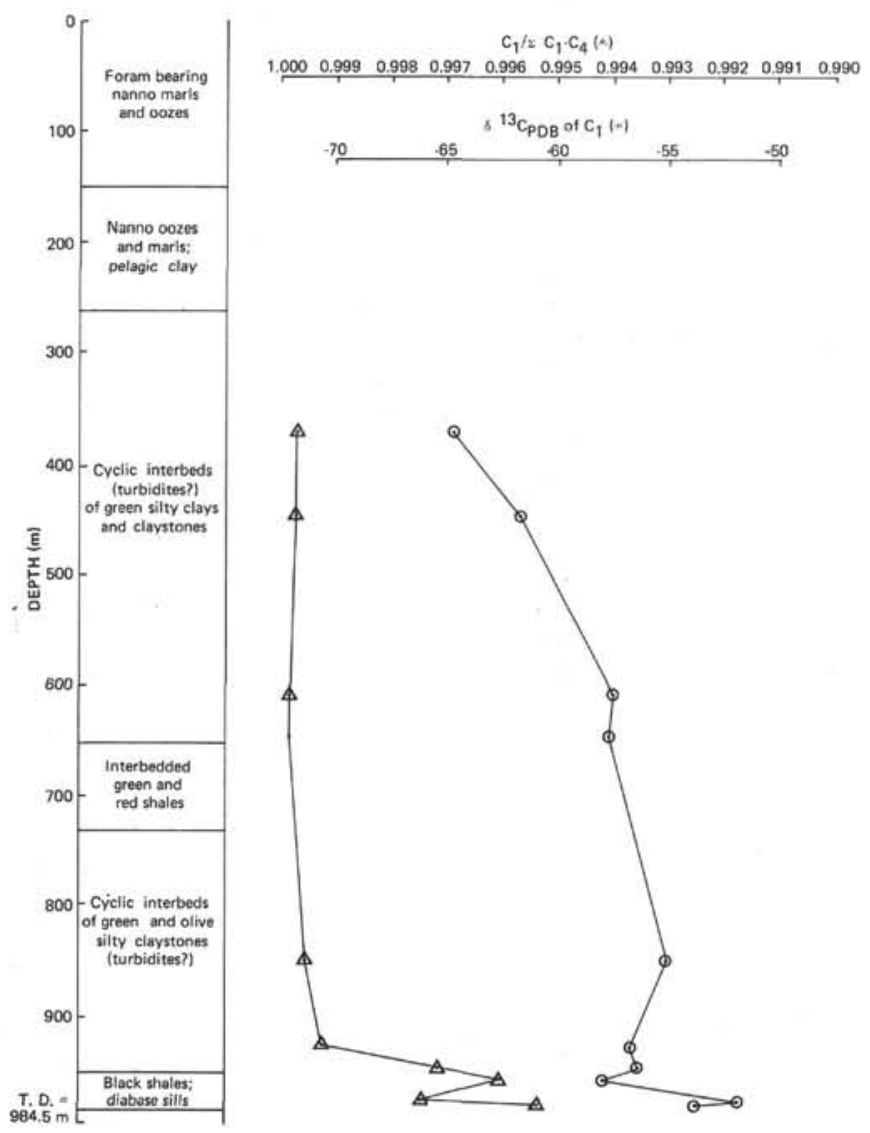

Figure 1. Lithologic information (Shipboard Report, Leg 41 ) is compared with the $C_{1} / \Sigma C_{1}-C_{4}$ ratio ( $\left.\Delta\right)$ and the $\delta^{13} \mathrm{C}$ of the methane (०) of Site 368. indicative of thermally produced hydrocarbons, whereas the concentration of higher hydrocarbons is lower than in samples from above and below the sills. It is possible that high temperatures in between the diabase sills caused thermal cracking of higher hydrocarbons to methane.

\section{Hole 369A}

The sediments sampled at Hole 369A, located on the Spanish Sahara continental slope, are predominantly argillaceous nannofossil marls. The composition of the gases indicates mixing of thermochemically generated hydrocarbons with biogenic methane, particularly below 400 meters (Figure 2).

The variations in the $\delta^{13} \mathrm{C}$ values and the $\mathrm{C}_{1} / \Sigma \mathrm{C}_{1}-\mathrm{C}_{4}$ ratio, between 250 and 350 meters, may represent variations in amount and type of deposited organic matter; these variations occur in a section where slump structures were observed (Shipboard Report, Leg 41).

\section{ACKNOWLEDGMENTS}

Work on this study was funded by NASA Grant NGR 05007-221.

\section{REFERENCES}

Claypool, G.E. and Kaplan, I.R., 1974. The origin and distribution of methane in marine sediments. In Kaplan,
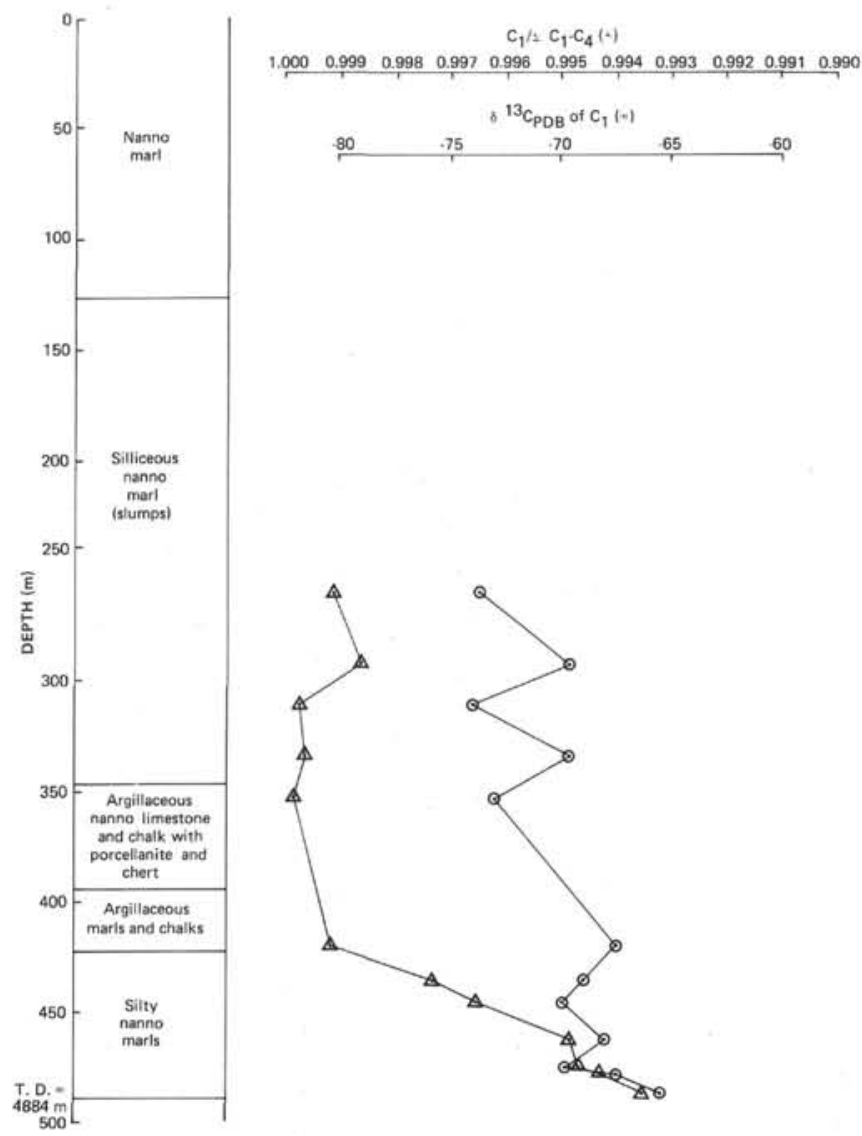

Figure 2. Lithologic information (Shipboard Report, Leg 41 ) is compared with the $C_{1} / \Sigma C_{1}-C_{4}$ ratio ( $\Delta$ ) and the $\delta^{13} \mathrm{C}$ of the methane $(\odot)$ at Hole $369 \mathrm{~A}$. 
I.R. (Ed.), Natural gases in marine sediments: New York (Plenum Press), p. 99-139.

Claypool, G.E., Presley, B.J., and Kaplan, I.R., 1973. Gas analyses in sediment samples from Legs 10, 11, 13, 14, 15, 18, and 19: In Creager, J.S., Scholl, D.W., et al., Initial Reports of the Deep Sea Drilling Project, Volume 19: Washington (U.S. Government Printing Office), p. 879884.

Gealy, E.L. and Dubois, R., 1971. Shipboard geochemical analysis Leg 7, Glomar Challenger. In Winterer, E.L.,
Riedel, W.R., et al., Initial Reports of the Deep Sea Drilling Project, Volume 7: Washington (U.S. Government Printing Office), p. 863.

Kaplan, I.R., Smith, J.W., and Ruth, E., 1970. Carbon and sulfur concentration and isotopic composition in Apollo 11 lunar samples: Geochim. Cosmochim. Acta, Supplement I, v. 1317.

Stahl, W., 1974. Carbon isotope fractionations in natural gases: Nature, v. 251, p. 134-135. 